Nalar: Jurnal Peradaban dan Pemikiran Islam

Vol. 3, No. 1, Juni 2019

\title{
Pendidikan Seksual Perspektif Islam dan Prevensi Perilaku Homoseksual
}

\author{
Lailul Ilham \\ Mahasiswa Pascasarjana Universitas Islam Negeri Sunan Kalijaga Yogyakarta \\ lailulilham44@gmail.com
}

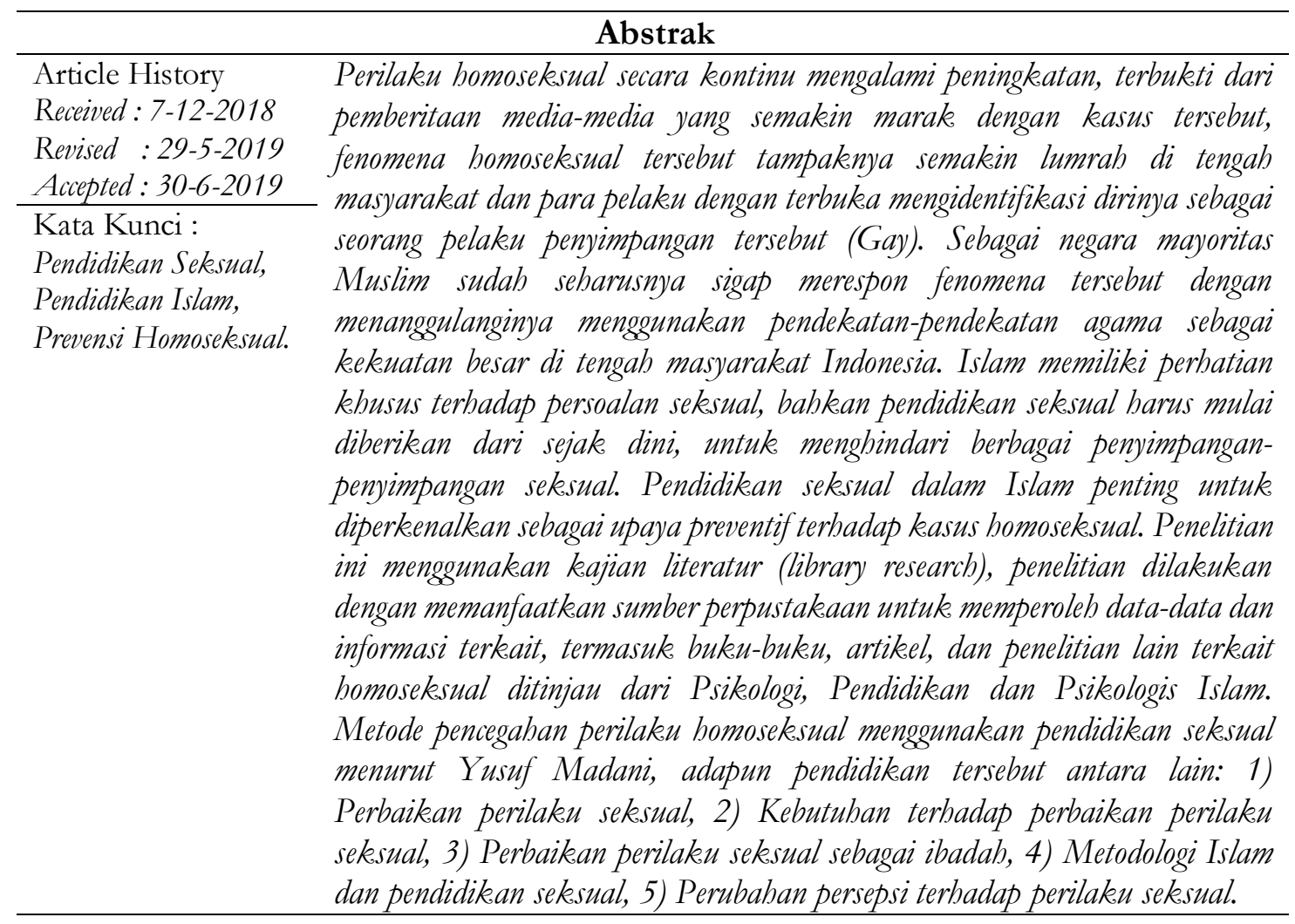

\section{Pendahuluan}

Syariat mengakui bahwa dorongan seksual merupakan suatu yang alamiah dan mesti dipenuhi oleh setiap individu karena dapat menurunkan tingkat ketegangan dan mempengaruhi kesehatan jiwa. Pemenuhan kebutuhan seks harus dilakukan dengan jalan yang sah (halal) yaitu berdasarkan aturan dan batasan-batasan, jalan memenuhi kebutuhan seks adalah dengan menikah karena menikah adalah jalan keluar terbaik bagi seseorang untuk menyalurkan dorongan seksualnya.

Namun persoalan seksual tidak selamanya ideal karena kerap terjadi penyaluran seksual yang tidak wajar, baik dalam proses penyaluran seksualnya atau pada objek penyaluran seksualnya, yaitu naluri seksual yang disalurkan tidak kepada lawan jenis atau disebut homoseksual (bagi pasangan laki-laki) atau lesbi (bagi pasangan perempuan). Penelitian ini fokus membicarakan kasus homoseksual sebagai penyimpangan perilaku seksual dan metode penanggulangan dengan pendidikan seksual dalam agama Islam. Satu artikel menyebutkan bahwa pendidikan seks harus diberikan sejak dini sebagai konsep dan bekal terhadap anak dalam menghadapi peristiwa seksualitas di kemudian hari. Pendidikan seks juga membantu seseorang dalam menjaga kesucian diri dan beradaptasi secara baik dengan naluri seksualnya (Safrudin, 2014). 
Nalar: Jurnal Peradaban dan Pemikiran Islam

Vol. 3, No. 1, Juni 2019

Fenomena Homoseksual semakin marak terjadi di kalangan masyarakat dan para pelaku semakin terbuka menunjukkan eksistensinya di ruang publik, hal tersebut terjadi karena adanya pergeseran nilai, hal-hal yang mulanya dianggap tabu oleh masyarakat, saat ini sudah menjadi wajar dan lumrah. Termasuk kasus perilaku homoseksual, melalui mediamedia telah banyak orang yang mengaku secara terbuka di ruang publik dan mengidentifikasi dirinya sebagai kaum LGBT (Lesbian, Gay, Biseksual dan Transgender). Kelompokkelompok LGBT semakin gencar berusaha menunjukkan eksistensinya dengan secara kontinu membangun citra dan melakukan upaya-upaya melalui berbagai sektor kehidupan untuk dapat diterima dan diakui oleh masyarakat luas.

Dalam satu penelitian disebutkan bahwa sampai tahun 2015 terdapat beberapa negara yang secara konstitusional melegalkan perkawinan sah pasangan homoseksual, diantaranya adalah Belanda (1996), Belgia (2003), Spanyol (2005), Kanada (2005), Afrika Selatan (2006), Norwegia (1993), Swedia (2008), Portugal (2009), Meksiko (2009), Islandia (2010), dan Argentina (2010), Uruguay (2010), Selandia Baru (2013), Perancis (2013), Denmark (2013, Inggris dan Wales (2013), Luksemburg (2014), Skotlandia (2014), Brazil (2013, Finlandia (2014), Irlandia (2015), Amerika Serikat (2015) (Ani Khairani, 2018).

Kemudin data di Indonesia (Syalaby) diperoleh berdasarkan laporan Kementerian Kesehatan yang dikutip dari Komisi Penanggulangan AIDS Nasional mengungkap jumlah Lelaki berhubungan Seks dengan Lelaki (LSL) alias Gay sudah mencapai angka jutaan. Hal ini dikuatkan berdasarkan estimasi Kemenkes pada 2012, terdapat 1.095.970 LSL baik yang tampak maupun tidak. Lebih dari lima persennya (66.180) mengidap HIV. Sementara, badan PBB memprediksi jumlah LGBT jauh lebih banyak, yakni tiga juta jiwa pada 2011. Kenaikan yang signifikan dibandingkan dengan jumlah pada tahun 2009 yang menyatakan bahwa populasi gay hanya sekitar 800 ribu jiwa (Syalaby, 2016).

Banyak media masa yang menguak fenomena tersebut dan memberitahukan kepada masyarakat, seperti yang dikutip dari Data Badan Pemberdayaan Perempuan dan Perlindungan Anak Provinsi Kepulauan Riau menyebutkan sekitar 3.000 anak laki-laki di bawah usia 18 tahun di kota Batam, Provinsi Kepulauan Riau, diduga sebagai penyuka sesama jenis (Liputan6, tanpa tahun). Kebanyakan berita mengungkapkan bahwa pelaku LGBT didominasi oleh kaum muda produktif. Hal ini tentu menjadi kekhawatiran sendiri bagi masyarakat terutama orangtua yang anak masuk kategori di usia sekolah.

Di Indonesia, kaum LGBT selalu mencari celah hukum untuk terus memperkuat eksistensinya sebagai komunitas sosial. Bagi para pelaku LGBT, menyukai sesama jenis merupakan fitrah kehendak dari Tuhan. Selain itu, dengan dalih bahwa LGBT juga merupakan Hak Asasi Manusia (HAM) mereka terus menuntut pemerintah khususnya Repubik Indonesia untuk mengakui, mempromosikan, memenuhi, dan melindungi hak-hak warga negaranya serta menghukum setiap pelaku pelanggaran hak sesuai dengan hukum hakhak manusia internasional (Triawan, 2008).

Data-data yang tersebut di atas menunjukkan semakin gencarnya penyebaran isu-isu dan praktik abnormalitas seksual di tengah masyarakat, jika kasus tersebut terus berlanjut dengan intensitas yang semakin masif sehingga intensitas persinggungan masyakarat dengan kaum perilaku homoseksual akan semakin sering, akhirnya peristiwa tersebut lambat laun akan merubah persepsi masyarakat dan memaklumi perilaku homoseksual sebagai suatu yang sah dan wajar. Kemudian bukan suatu yang mustahil jika terdapat negara-negara yang mulai muncul ke permukaan menyusul negara-negara lain dalam melegitimasi praktik abnormalitas seksual tersebut. Sehingga tindakan-tindakan pengentasan lebih-lebih penanggulangan mesti haus dilakukan oleh masyarakat dan salah satunya dengan kekuatan agama yang menjadi pegangan umum masyarakat Indonesia. 
Nalar: Jurnal Peradaban dan Pemikiran Islam

Vol. 3, No. 1, Juni 2019

Salah satu penelitian menjabarkan pendidikan seksual bagi anak (3-5 tahun) yaitu dengan memperkenalkan nama-nama anggota tubuh beserta fungsinya kepada anak (termasuk alat reproduksi), mempekenalkan perbedaan alat kelamin laki-laki dan perempuan serta perbedaan alat kelamin anak-anak dan dewasa, memperkenalkan sensasi-sensasi yang dimunculkan di area alat kelamin sebab pada usia tersebut anak sudah mulai menjelajahi dan merasakan sensasi kenikmatan tersebut (Sugiasih, tanpa tahun). Serta beberapa penelitian sejenis terkait pendidikan seksual dan penanggulangan penyimpangan seksual dengan metode yang beragam.

Dalam situasi demikian dibutuhkan langkah antisipatif sebagai usaha preventif dengan menjauhkan genarasi muda dari kesalahpahaman informasi seksualitas sehingga tidak terjerumus pada perilaku-perilaku penyimpangan seksual. Melihat pendidikan seksual dalam Islam yang cukup ekslusif dan memandang serius terhadap pentingnya anak-anak untuk segera memperoleh pendidikan seksual, hal tersebut dapat dielaborasi menjadi suatu rancangan tindakan untuk menjauhkan generasi muda dari pelampiasan seksual yang diharamkan agama Islam, serta menjauhkan dari perilaku homoseksual.

Penelitian ini adalah studi literatur, menggunakan pendekatan kualitatif, yaitu pendekatan untuk memahami perilaku, persepsi, motivasi, serta tindakan lainnya (Soetady, 2000). Penelitian ini sebagai studi atas pendidikan seksual dalam perspektif Islam serta potensinya terhadap pencegahan perilaku abnormalitas seksual seperti kasus homoseksual. Adapun metode pengumpulan datanya dengan menghimpun literatur-literatur berupa bukubuku, jurnal, artikel serta penelitian-penelitian ilmiah yang terkait dengan pendidikan seksual dalam Islam. Kemudian dilakukan analisis dengan berdasarkan pada telaah potensi pendidikan seksual dalam Islam kaitannya dengan pencegahan terhadap perilaku homoseksual.

\section{Homoseksual Sebagai Perilaku Menyimpang}

Perkembangan mutakhir tentang perbincangan terkait isu seks mulai ramai kembali setelah maraknya fenomena LGBT (Lesbian, Gay, Biseksual, dan Transgender). LGBT merupakan akronim yang baru-baru ini digunakan untuk menunjukkan para pelaku penyimpangan seksual yaitu lesbian, gay, biseksual, dan transgender (Montreal, tanpa tahun). Menurut Kartini kartono, LGBT masuk dalam penggolongan abnormalitas seksual yang disebabkan adanya partner seks yang juga abnormal (Kartono, 2009).

Dalam Pedoman Penggolongan dan Diagnosis Gangguan Jiwa di Indonesia III (DepKes, 1998), homoseksualitas termasuk dalam kategori gangguan psikoseksual dan disebut sebagai orientasi seksual egodistonik, yaitu "identitas jenis kelamin atau preferensi seksual tidak diragukan, tetapi individu mengharapkan yang lain disebabkan oleh gangguan psikologis dan perilaku serta mencari pengobatan untuk mengubahnya". Menurut pendapat di atas bahwa homoseksualitas dianggap sebagai kelainan jika individu tidak menerima identitas seksual dan bermaksud untuk mengubahnya.

Istilah homoseksual dan heteroseksual merujuk pada orientasi seksual seseorang. Orientasi seksual menunjuk pada jenis kelamin pasangan erotis, cinta ataupun afeksi yang dipilih. Orientasi seksual terbentuk mulai saat hormon-hormon seksual berkembang, yaitu pada saat seseorang memasuki usia remaja. Sebelum masa tersebut, ketertarikan kepada orang lain masih belum dapat dianggap sebagai ketertarikan seksual (Oetomo, 2001), dan gay adalah seorang homoseksual karena ia laki-laki dan pasangan erotisnya juga laki-laki.

Beberapa aspek dan faktor yang melatarbelakangi kasus penyimpangan seksual secara komprehensif. Homoseksual adalah orang yang diserang gejala berkeinginan berhubungan 
Nalar: Jurnal Peradaban dan Pemikiran Islam

Vol. 3, No. 1, Juni 2019

dengan orang yang sejenis saja. Mungkin cinta sejenis ini beralasan, dan mungkin pula hanya sepihak, yaitu yang melakukan hal itu hanya satu orang saja. Bahkan hubungan itu mungkin lebih jauh dari itu, yaitu ingin melakukan hubungan seksuil dengan orang yang sama jenis kelaminnya. Keadaan seperti ini mungkin terjadi pada orang-orang yang hidup terpisah jauh dari jenis lain, atau tidak mungkin berhubungan dengan jenis lain, disebabkan oleh tugas, adat kebiasaan atau peraturan yang sangat keras, yang tidak memberi kesempatan untuk berkenalan dengan jenis lain (Darajat, 1979).

Homoseksual masuk dalam kategori ketidakwajaran seksual (seksual perversion), itu mencakup perilaku-perilaku seksual atau fantasi-fantasi seksual yang diarahkan pada pencapaian orgasme lewat relasi diluar hubungan kelamin heteroseksual, dengan jenis kelamin yang sama, atau dengan partner yang belum dewasa, dan bertentangan dengan norma-norma tingkah laku seksual dalam masyarakat yang tidak bisa diterima secara umum (Kartono, 2009).

Namun dalam beberapa pernyataan disebutkan bahwa kasus penyimpangan seksual bersifat majemuk, artinya walaupun dari salah satu deviasi ada yang paling dominan namun tidak menutup kemungkinan itu bergandengan dengan perilaku menyimpang yang lain. Misalkan seperti yang disebutkan oleh Kartini Kartono bahwa gejala fatishisme dan ekshibisionisme biasa dialami oleh individu secara bersamaan dengan tingkah-laku homoseksual, ataupun bisa juga homoseksualitas dan biseksualitas bisa bersamaan dengan heteroseksualitas yang memuaskan.

Pada umumnya, abnormalitas pemuasan atau penyaluran kebutuhan seksual, terbagi dalam tiga golongan; Pertama, ada dorongan-dorongan seksual yang abnormal. Kedua, ada partner seks yang abnormnal. Ketiga, ada cara-cara yang abnormal dalam pemuasan dorongan seksualnya. Kemudian beberapa hal yang menjadi sebab-sebab penyimpangan seksual dengan menganut pada teori komprehensif, dapat diringkas sebagai berikut (Kartono, 2009): Pertama, Sebab genetis atau faktor-faktor konstitusional yang herediter atau predisposisional. Kedua, Pengalaman-pengalaman anak pada masa kanak-kanak yang sangat muda (tahun-tahun awal perkembangannya). Ketiga, Proses belajar secara umum selama masa kanak-kanak. Keempat, Kejadian-kejadian yang berasosiasi dengan awal tingkah laku seksual pada usia pubertas dan adolescence.

Kemudian diungkapkan pula dalam teori yang menjelaskan sebab-sebab homoseksualitas; antara lain (Kartono, 2009): Pertama, Faktor herediter berupa ketidakseimbangan hormon-hormon seks. Kedua, Pengaruh lingkungan yang tidak baik/tidak menguntungkan bagi perkembangan kematangan seksual yang normal. Ketiga, Seseorang selalu mencari kepuasan relasi homoseks, karena ia pernah mengahayati pengalaman homoseksual yang menggairahkan pada masa remaja. Keempat, Atau, seorang anak laki-laki pernah mengalami pengalaman traumatis dengan ibunya, sehingga timbul kebencian/antipati terhadap ibunya dan semua wanita. Lalu muncul dorongan homoseks yang jadi menetap.

Sebagaimana disebutkan dalam teori psikoanalisa, bahwa kondisi penentu pada tingkah laku seksual yang menyimpang sudah diletakkan pada pengalaman-pengalaman masa kanakkanak yang sangat muda; misalnya komplek oedipal, komplek astral, latar belakang familiar dengan penyimpangan-penyimpangan seksual, homoseksualitas di kalangan keluarga, dan lain-lain. Pada orang-orang homoseks biasanya terdapat tipe ibu-ibu yang terlalu banyak melindungi anak-anaknya (overprotective), mempunyai ikatan sangat intim dan mengikat sifatnya, tetapi mempunyai kewibawaan mengontrol yang kuat dan banyak menuntut. Sedang ayahnya pada umumnya lepas, terpisah, tidak ada atau jarang ada di rumah, bersikap acuh tak acuh; bahkan sering bermusuh dengan anak laki-lakinya. Juga perkawinan yang mendidik 
Nalar: Jurnal Peradaban dan Pemikiran Islam

Vol. 3, No. 1, Juni 2019

anak-anaknya secara abnormal, biasanya membutuhkan remaja-remaja dan adolescence dengan penyimpangan seksual (Kartono, 2009).

Kemudian dikuatkan dalam teori belajar sosial, yang tidak secara spesifik menekankan pengalaman usia kanak-kanak, akan tetapi menggarisbawahi pengalaman-pengalaman seksual yang pertama kalinya, hingga anak mencapai orgasme, biasanya pada masa pubertas dan adolescence yang menjadi faktor kritis untuk menetapkan orientasi seksual seseorang. Proses belajar yang berlangsung sesudah pengalaman pertama/intial tadi akan berperan besar sekali dalam pengembangan fantasi-fantasi seks yang menyimpang, sehingga menjadi kebiasaan masturbasi, atau pembentukan perilaku seksual yang abnormal lainnya. Ternyata bahwa fantasi-fantasi itu merupakan nilai perangsang yang kuat sekali bagi penentu perilaku seksual seseorang (Kartono, 2009).

Berdasarkan beberapa faktor homoseksual yang tersebut diatas, secara spesifik samasama menyebutkan pengalaman pada fase anak-anak menjadi salah satu faktor fundamental individu dapat mengidap perilaku penyimpangan seksual, kemudian dikuatkan oleh dua teori, yaitu teori psikoanalisis yang menekankan bahwa kompleksitas pengalaman individu pada masa anak-anak menjadi faktor pendorong terbesar bagi anak untuk berperilaku menyimpang termasuk dalam aspek seksual. Kemudian teori belajar sosial menitikberatkan pada pengalaman seksual pertama individu, dan pengalaman tersebut (dapat) terjadi pada fase akhir masa anak-anak atau pada masa awal remaja.

Kemudian juga pernyataan Piaget yang dijelaskan dalam teori kognitifnya bahwa dalam perkembangan kognisi, anak usia lahir sampai dua tahun dapat mengaktifkan semua alat indera yang berfungsi untuk menyerap informasi. Sehingga dapat diketahui bahwa masa anak-anak merupakan fase sentral dimulainya perkembangan naluri seksual yang sebenarnya, pada usia anak-anak pula memiliki kemampuan kuat menangkap situasi lingkungan sehingga menjadi momen tepat untuk memberikan bimbingan seksual di usia tersebut, sebagaimana pendidikan seksual dalam perspektif islam yang mengarahkan orangtua untuk menjauhkan anak dari perilaku seksual menyimpang.

Penulis berasumsi bahwa ajaran islam yang menekankan pendidikan seksual yang dimulai sejak usia anak-anak dapat berfungsi ganda yaitu selain sebagai bekal pendidikan seksual, juga menjadi upaya preventif terhadap abnormalitas seksual. Aspek pendidikan seksual dalam Islam tidak hanya menyangkut etika memenuhi kebutuhan seks tapi secara spesifik Islam juga menjelaskan kepada siapa (seharusnya) seksual disalurkan serta dengan prasyarat yang jelas. Dengan demikian anak dapat mengetahui etika seksual sejak dini, serta dapat menghindari perilaku seksual yang menyimpang dari syariat Islam, yaitu melampiaskan kebutuhan seksual terhadap sesama jenis (homoseksual).

Kemudian di tengah maraknya kasus homoseksual, khususnya di negara Indonesia, seakan-akan pendidikan seksual Islam menemukan momennya sendiri, artinya pendidikan seks dalam Islam menjadi penting dilakukan, tidak hanya sebagai pendidikan namun jauh lebih urgen yaitu sebagai langkah preventif atas semakin meningkatnya kasus homoseksual di tengah-tengah masyarakat.

\section{Homoseksual dalam Pandangan Islam}

Dalam sejarah peradaban manusia, fenomena penyimpangan seksual sudah muncul jauh sebelum zaman Nabi Muhammad SAW, tepatnya pada masa Nabi Luth. Allah mengutus nabi Luth ke tengah-tengah kaum yang memiliki kebiasaan abnormalitas seksual yaitu homoseksual dan dikenal dengan sebutan kaum sodom. Hampir dalam semua kitab tafsir mengabadikan kisah tersebut, terlebih ketika menyingkap kandungan ayat-ayat yang berkaitan dengan kisah nabi Luth. 
Nalar: Jurnal Peradaban dan Pemikiran Islam

Vol. 3, No. 1, Juni 2019

Dalam Al-Qur'an disebutkan bahwa Allah tidak menghendaki perilaku menyimpang tersebut dan secara tekstual mengindikasikan kemarahan Allah terhadap kaum negeri sodom yang mempraktekkan homoseksual dan lesbian (liwath). Sebagaimana firman Allah dalam surat Al-A'rof [7]: 80-81 yang artinya "Dan (Kami juga telah mengutus) Luth (kepada kaumnya). (Ingatlah) tatkala dia berkata kepada kaumnya: "Mengapa kamu mengerjakan perbuatan keji itu, yang belum pernah dikerjakan oleh seorang-pun (di dunia ini) sebelummu?" Sesunggubnya kamu mendatangi lelaki untuk melepaskan nafsumu (kepada mereka), bukan kepada wanita, malah kamu ini adalah kaum yang melampaui batas" (Dacholfany, 2016).

Redaksi ayat "ata'tûna al-fâhisyata mâ sabaqokum bihâ min abadin min al-'alamîn (Mengapa kamu mengerjakan perbuatan keji itu, yang belum pernah dikerjakan oleh seorangpun (di dunia ini) sebelummu?)". Lafadz tersebut mengindikasikan bahwa kasus sodom yang dilakukan kaum nabi Luth, merupakan kasus penyimpangan seksual pertama dan belum pernah terjadi pada masyarakat-masyarakat sebelumnya, dan Allah mengutuk pelaku dan perilaku menyimpang tersebut.

Secara tegas Islam mengharamkan dan menentukan sanksi tegas terhadap praktik homoseksual, dan mengutuknya sebagai tindakan haram yang menyimpang dari normalitas seksual dalam ajaran Islam. Sebagaimana disebutkan dalam surat An-Niasa' [4]: 1 yang artinya "dan daripada keduanya Allah memperkembang-biakkan laki-laki dan perempuan yang banyak" (Kemenag, 2010), penggalan ayat tersebut mempertegas bahwa homoseksual benar-benar mengancam keseimbangan dan tujuan dasar manusia yang mesti menciptakan keselarasan hidup dengan terus bereproduksi dan melahirkan generasi baru untuk melanjutkan tanggungjawab kekhalifahan di dunia, tujuan ini mustahil tercapai jika praktik homoseksual semakin menunjukkan peningkatannya.

Dalam literatur lain Dadang Hawari menyebuutkan bahwa homoseksual adalah ketertarikan secara perasaan (kasih sayang, hubungan emosional) dan atau secara erotik, terhadap jenis kelamin yang sama, dengan atau tanpa hubungan seks dengan mulut atau dubur. Homoseksual ini merupakan satu bentuk perilaku seks yang menyimpang. Sedangkan definisi lesbian adalah sama dengan homoseksual, namun lesbianisme berlaku untuk sesama pasangan perempuan (Hawari, 2013).

Perbuatan sodomi yang dilakukan oleh para homoseksual dijadikan kategori perbuatan yang merupakan gabungan dari segala perbuatan keji. Akibat hubungan homoseksual tersebut dalam kondisi seluruh kerusakan yang disebabkan oleh perbuatan tersebut sudah tidak dapat dihitung lagi dan tidak ada yang mengetahui rinciannya kecuali Allah. Perbuatan sodomi yang dilakukan oleh para homoseksual dijadikan kategori perbuatan yang merupakan gabungan dari segala perbuatan keji. Akibat hubungan homoseksual tersebut dalam kondisi seluruh kerusakan yang disebabkan oleh perbuatan tersebut sudah tidak dapat dihitung lagi dan tidak ada yang mengetahui rinciannya kecuali Allah (AlJauziyah, 2006).

\section{Pendidikan Seksual dalam Islam}

Naluri seksualitas merupakan potensi alamiah setiap manusia dan merupakan satu kelebihan yang diberikan kepada manusia. Dalam pandangan Islam, naluri seksual tidak sebagai kelebihan untuk dibanggakan atau disalurkan sesuai kehendak pribadi, namun secara tegas Allah juga menetapkan ajaran-ajaran yang mengatur etika penyaluran kebutuhan seksual tersebut, sebagaimana diatur dalam syariat islam. Segala aturan yang disyariatkan menunjukkan sebuah cita-cita Islam untuk membentuk kehidupan manusia yang sehat, harmonis dan berkelanjutan. 
Nalar: Jurnal Peradaban dan Pemikiran Islam

Vol. 3, No. 1, Juni 2019

Pendidikan seks (sex education) merupakan pendidikan perilaku yang baik, menjunjung tinggi nilai-nilai kemasyarakatan serta membantu seseorang menghadapi persoalan hidup yang berpusat pada naluri seks yang timbul dalam bentuk tertentu dan merupakan pengalaman manusia yang normal (Sri Esti Muryani, 2008). Orientasi pendidikan seks bertujuan untuk menjelaskan etika penyaluran kebutuhan seksual yang benar sehingga tidak terjerumus pada tindakan-tindakan penyimpangan seksual. Pendidikan seks tidak hanya terbatas pada perkenalan dengan anatomi, fisiologis, penyakit kelamin dan perilaku seks menyimpang, namun lebih dari itu pendidikan seks membentuk kematangan emosional anak serta sikap-sikap dalam merespon naluri seksualitasnya.

Sebagaimana tawaran gagasan dalam mengatasi kasus LGBT adalah Six continum of Transgender Counseling (Enam Kontinum dari Transgender Counseling) yaitu enam kontinum panduan bagi seorang konselor, psikolog, psikiater atau profesi helper lainnya dalam menangani kasus LGBT (Azmi, 2015): 1) Self, yaitu konselor mendorong konseli untuk menyadari identitas atau kodrat dirinya (self), 2) Differential of feeling, yaitu pengidentifikasian konseli terhadap perbedaan perasaan kepada teman-teman dan lingkungan sekitarnya. Pada tahap ini, konseli diajak mengkonstruk kembali pikiran, perasaan dan tindakan kemudian mendeklarasikan diri bahwa dirinya normal (bukan LGBT), 3) Spiritual Intervention, yaitu proses intervensi agama, konseli diberikan pemahaman terkait pandangan agama terhadap kasus LGBT yang mungkin sedang dialaminya. Kontinum ini mungkin tidak dibahas dalam seting konseling dunia (khususnya negara eropa) karena kontinum menggunakan dasar agama dan itu merupakan salah satu topik sensitif dan privat sehingga tidak pernah digunakan oleh konselor-konselor barat kecuali dalam seting konseling pastoral atau konseling berbasis agama. 4) Acceptane of environmental, yaitu penerimaan diri konseli terhadap lingkungan dan melakukan penyesuaian diri dengan kodrad dan latar belakang dirinya.

Kemudian pendidikan pengentasan penyimpangan seksual berikutnya berdasrkan tawaran Husaini terkait metode penyelesaian LGBT dalam lingkup yang luas dan melibatkan banyak pihak, yaitu (Husaini, 2015): Melakukan peninjauan kembali peraturan perundangundangan yang memberikan kebebasan melakukan praktik hubungan seksual sejenis. Perlu ada perbaikan dalam pasal 292 KUHP agar pasal tersebut mencakup perbuatan hubungan seksual sejenis dengan orang yang sama-sama dewasa. Kemudian mendorong masjid-masjid besar untuk membuka klinik LGBT, yang memberikan bimbingan dan pengobatan keagamaan kepada penderita LGBT (secara langsung atau media online). Kemudian kaum muslim (khususnya), memberikan pendekatan yang integral dan mengakui eksistensi penderita LGBT di tengah masyarakat. Sebab, bagaimana pun LGBT merupakan bagian dari manusia yang harus diberikan hak-haknya sesuai prinsip kemanusiaan, sekaligus disadarkan kekeliruan perilakunya. Kemudian setiap muslim harus aktif menyuarakan amar ma'ruf dan nabi mungkar, dengan menolak legalisasi LGBT dan menjelaskan dampak-dampak kesehatan medis dan psikologis akibat perilaku LGBT. Kemudian terakhir yaitu mendukung orangorang yang sembuh dari kasus LGBT kemudian difasilitasi supaya membuat himpunan dan gerakan bersama untuk mendemonstrasikan kesembuhannya kepada rekan-rekan penderita LGBT supaya menjadi contoh bagi yang lain.

Berdasarkan beberapa data di atas terlihat bahwa perhatian Islam terhadap kasus LGBT cukup komprehensif, terbukti dari hukum Islam yang tidak hanya mengutuk perilaku penyimpangan tersebut melainkan hal-hal yang menyebabkan atau mendorong individu ke arah penyimpangan seksual tersebut juga di haramkan. Syariat Islam mengharamkan praktik perzinahan, homoseksual, dan semua hal yang menyebabkan keduanya, sehingga secara konstitusi Islam memberikan perlindungan kepada individu untuk terhindar dari penyimpangan tersebut. 
Nalar: Jurnal Peradaban dan Pemikiran Islam

Vol. 3, No. 1, Juni 2019

Kemudian Abdul Aziz El-Qussy menyatakan bahwa pendidikan seks sebagai upaya sosialisasi pengalaman seksual yang benar kepada seseorang dengan tujuan seseorang dapat menyesuiakan diri dalam kehidupannya di masa depan dan hasilnya seseorang dapat menentukan sikap dan mental yang baik terhadap masalah seks dan masalah keturunan. Ali akbar juga menguatkan bahwa pendidikan seks pada substansinya berisi adab seksual serta mengandung nilai-nilai luhur dan dapat dipertanggungjawabkan dari segi kesehatan (dalam Aziz, 2014). Etika seksual dalam Islam sangat komprehensif, Islam tidak hanya mengatur tatacara melakukan hubungan seksual namun jauh lebih spesifik mengatur kepada siapa (objek) kebutuhan seksual disalurkan atau siapa yang boleh menjadi partner seksual berdasarkan syariat. Dalam penelitian ini akan disebutkan hal-hal yang fundamental terkait etika seksualitas, partner seksual yang benar (lawan jenis), dan hubungan seksual dilakukan di atas ikatan pernikahan.

Islam mengajarkan adab-adab seksual, adab-adab tersebut berbentuk hukum halal, haram, dan makruh yang mengatur syahwat seksual manusia. Pemenuhan kebutuhan seksual yang tidak sesuai atau melanggar syariat yang telah digariskan, maka masuk dalam kategori hukum haram dengan sanksi normatif dan sosial yang sama-sama berlaku. Fenomena di atas menunjukkan tingginya perhatian Islam terhadap persoalan seksualitas, dengan menjelaskan secara komprehensif dan mengklasifikasi metode pendidikan seksual bedasarkan fase perkembangan individu. Pendidikan seksual terhadap anak-anak berbeda dengan terhadap remaja, pendidikan disesuaikan dengan karakteristik dan kematangan individu di masingmasing fase perkembangan. Sebagaimana firman Allah: "dan apabila anak-anak kalian telah mencapai usia baligh, maka hendaklah mereka meminta izin pada setiap waktu".

Artinya islam benar-benar menganjurkan bagi anak yang mumayyiz atau baligh supaya dilatih meminta izin (isti dzan) ketika hendak memasuki kamar orang dewasa. Pendidikan tersebut menunjukkan bahwa Islam secara detail mengklasifikasi pendidikkan seksual dalam setiap fase perkembangan. Pada masa anak-anak metode pendidikan seksual cenderung mengarah kepada usaha preventif, menyangkut perhatian dan larangan seorang anak melihat fisik lawan jenis sesuai kehendak sendiri atau melakukan tindakan yang mengarah pada seksualitas sebagaimana yang dilakukan pada perkembangan sebelumnya (Madani, 2003).

Adapun kaidah-kaidah preventif dalam pendidikan seksual bagi anak, antara lain (Madani, 2003): Pertama: Pendidikan seks dan fiqih pada anak. Ketika anak telah mampu berfikir membedakan antara baik dan buruk, anak perlu diberi pengetahuan tentang seks yang sesuai dengan usianya dan perlahan diajari hukum-hukum fiqih, terutama etika-etika seks yang dibutuhkannya. Selain mengajarkan hukum fiqih anak juga perlu dilatih secara praktis memahami hukum-hukum dengan membiasakannya dalam kegiatan sehari-hari dan mengamati sejauh mana keberhasilan anak yang mumayiz dalam mengaplikasikannya. Kedua: Meminta iz̨in (isti'dzan). Syariat Islam menekankan etika meminta izin sejak usia kanak-kanak, mengingat hal tersebut merupakan pendahuluan bagi kaidah-kaidah kesopanan. Melalui surat an-Nuur (ayat 58 dan 59) menunjukkan bahwa Islam menoleransi anak yang belum baligh, terutama yang mumayir, memasuki kamar orang lain, termasuk kamar kedua orang tuanya, kecuali pada tiga waktu, yaitu: sebelum subuh, ketika melepas lelah pada siang hari, dan setelah shalat isya'.

Ketiga: Menaban pandangan dan menutup aurat. Anak yang sudah usia baligh dan mukalaf (telah terkena beban syariat) wajib menutup aurat dari pandangan anak yang mumayiz, sebagaimana ia juga diharamkan memandang aurat anak yang mumayiz atau menyentuhnya dengan dorongan syahwat. Hal itu karena anak yang mumayiz dapat mengingat dengan baik sesuatu yang dilihatnya. Para faqaha pun menegaskan bahwa setiap laki-laki dan perempuan wajib menutup aurat mereka dari pandangan orang yang sudah berusia baligh dan dari anak 
Nalar: Jurnal Peradaban dan Pemikiran Islam

Vol. 3, No. 1, Juni 2019

yang mumayiz - yang belum balig, yaitu anak atau remaja yang berada pada suatu tingkat kecerdasan dan kesadaran tertentu. Ia terpengaruh oleh berbagai hal dan dapat memikirkannya tanpa batasan usia.

Keempat: Menjaubkan anak dari aktivitas seksual. Menjauhkan anak (khususnya mumayiz) dari melihat aktivitas seksual antara suami dan istri karena sangat bahaya terhadap kejujurannya di masa depan sehingga aktivitas seksual diantara kedua orang tua hendaknya dilakukan di tempat rahasia dan tersembunyi dari anak. Kadang-kadang masalah ini memunculkan kesukaan terhadap perzinahan, ketertarikan pada sesama jenis, atau fenomena aktivitas seksual menyimpang lainnya sehingga Islam menekankan isti'dran untuk mencegah anak dari pemandangan apapun yang dapat membangkitkan hasrat seksualnya, serta wahana untuk menutup aurat dan melindungi kemuliaan anggota keluarga. Kelima: Pemisaban tempat tidur anak. Melalui pemisahan ini anak-anak jauh dari kamar kedua orang tua dan diasingkan dari tempat yang di dalamnya dilakukan aktivitas seksual. Selain itu, pemisahan anak laik-laki dan perempuan, di mana masing-masng jenis memiliki kemar tersendiri, menghidarkan anakanak dari sentuhan badan yang dapat menyebabkan rangsangan seksual yang berbahaya. Jelaslah bahwa pemisahan tempat tidur merupakan metode pendidikan di mana setiap anggota keluarga merasakan sesuatu yang menjadi miliknya dan orang lain tak bisa menggunakannya tanpa seizinnya.

Keenam: Tempat tinggal yang layak, dalam pencegahan perilaku seksual menyimpang bagi anak dibutuhkan tempat tinggal yang cukup luas dan memenuhi unsur-unsur kesehatan fasilitas ruangan memberikan ketenangan dan kebahagiaan tersendiri bagi penghuninya. Narasi-narasi syariat Islam menunjukkan pentingnya rumah yang luas atau memadai sebab tanpa rumah yang memadai kemampuan mendidik dan mengaplikasikan kaidah-kaidah Islam menjadi terhambat, bagaimana akan diajarkan perilaku isti'dzan kepada anak jika dalam satu rumah hanya ada satu kamar tidur, dan bagaimana cara memisahkan tempat tidur anak dari orangtua atau dari saudara yang berbeda jenis kelaminnya. Ketujub: Larangan terhadap tindakan erotis, syariat Islam secara tegas melarang tindakan-tindakan erotis yang dapat membangkitkan gairah seks pada anak-anak, remaja, dan pemuda. Sebab, tindakan erotis dapat menjadi faktor munculnya penyimpangan seksual, tindakan erotis seperti ciuman, tidur di bawah satu selimut, anak laki-laki dihias sebagaimana perempuan dan sebaliknya. Hal tersebut merupakan tindakan berbahaya karena memiliki rangsangan terhadap psikologis dan mental anak, sekalipun pengaruh rangsangan tidak terlihat jelas terhadap anak.

Kedelapan: Mengawasi kematangan seksual dini. Yaitu pengawasan terhadap kematangan seksual dini dan faktor-faktor yang menyebabkannya serta mengenali perubahan-perubahan yang menyertainya. Pendidikan perlu melakukan persiapan pendidikan seksual bagi anak mumayiz untuk mengantisipasi masalah-masalah yang mungkin muncul akibat terjadinya kematangan seksual secara dini, sebab jika gagal dalam memberikan pengawasan sangat mungkin anak akan terjebak dalam masalah seksual yang membahayakan kesucian dan moralnya. Kesembilan: Mengarabkan anak mumayiz untuk memproduktifkan waktunya. Syariat Islam menekankan mengarahkan anak kecil untuk melakukan kebaikan-kebaikan dan kegiatan yang menyenangkan tetapi berguna dan mubah menurut syariat. Bahkan pendidik harus berusaha mengaitkan permainan dan sebagainya dengan tugas peribadatan dan pendalaman penalaran anak, terkadang ada orang tua yang kurang memiliki kesadaran tersebut sehingga tidak memberikan kesempatan dan pengarahan kepada anak untuk memanfaatkan waktu dan merasakan capaian-capaian diperoleh serta terus berinovasi berdasarkan potensi dasarnya.

Kesepulub: Mengajarkan halal-haram dalam program-program media informasi. Hendaknya orang tua selalu membimbing anak dalam mengkonsumsi berbagai media informasi, oang tua harus mendorong anak berinteraksi dengan sebagian media dan menghindari sebagian media 
Nalar: Jurnal Peradaban dan Pemikiran Islam

Vol. 3, No. 1, Juni 2019

yang lain sesuai kriteria-kriteria syariat. Proses pengawasan tersebut membutuhkan kerjasama semua pihak dalam keluarga supaya proses pengawasan berjalan baik sehingga dapat dipastikan bahwa anak mampu bersikap disiplin dan jujur, baik dalam hal seksualitas maupun dalam masalah lain. Kesebelas: Hukuman. Dalam Islam hukuman berlaku kepada semua aktivitas individu (tidak hanya dalam kasus seksual), hukuman dibutukan dalam kasus tertentu apabila nasihat dan bimbingan sudah tidak efektif menyelesaikan masalah, maka dibutuhkanlah metode hukuman. Hukuman boleh dijatuhkan namun sebagai cara terakhir dalam mendidik setelah upaya-upaya lain tidak berhasil, namun pemberian hukuman tetap harus berdasarkan aturan syariat, tidak boleh melampaui batas-batas tertentu. Kedua belas: Pernikahan di usia dini, pernikahan dini merupakan solusi terakhir dalam upaya pendidikan seksual anak untuk menjaga kesucian anak dan terhindar dari berbagai penyimpangan seksual. Sebagian pakar pendidikan memutuskan ditempuhnya pernikahan diri sebagai sebuah langkah pencegahan dan penyembuhan sekaligus; langkah pencegahan dalam menghadapi faktor-faktor penyimpangan yang telah menanti, dan langkah penyembuhan bagi kedurhakaan yang dilakukan remaja melawan nilai-nilai dan pernikahan di usia dini merupakan metode pendidikan yang telah dijalankan dalam masyarakat muslim untuk menyelesaikan masalah seksual.

\section{Pencegahan Perilaku Homoseksual melalui Pendidikan Seksual Islam}

Beberapa metode pendidikan seksual dalam Islam dalam uraian Yusuf Madani, kiranya perlu mendapat perhatian serius, sebab dapat berpotensi mencegah dan menghindarkan anak dari perilaku homoseksual. Adapun beberapa jenis pendidikannya sebagai berikut:

Pertama: Rubah Perilaku Seksual anak. Dalam tahapan pertama ini, orang tua atau tenaga pendidikan fokus memperbaiki perilaku seksual anak yaitu dengan mendidik anak menggunakan langkah-langkah, kaidah-kaidah, dan pemikiran yang dapat mencegah anak dari kemungkinan-kemungkinan terjerumus dalam perilaku penyimpangan seksual dan menyembuhkan bagi anak yang sudah terindikasi kasus tersebut, baik penyimpangan yang didorong oleh faktor genetik/bawaan atau oleh pengaruh lingkungan. Kemudian Yusuf Madani menambahkan urgensi pendidikan seksual kepada individu di fase perkembangan awal (anak-anak), momen tersebut sangat penting dalam menentukan lingkungan hidup anak, dengan bantuan lingkungan yang islami (religius, kondusif) dapat mewujudkan kesucian seksual dan kemampuan beradaptasi secara benar terhadap perilaku seksual di masa baligh, serta masa-masa sebelum dan sesudahnya (Madani, 2003).

Kedua: Membangan Persepsi yang Sama (anak dan orang tua). Dalam tahapan kedua, orang tua atau tenaga pendidikan melakukan indoktrinasi terhadap anak supaya terbentuk pandangan yang sama terhadap kasus homoseksual, artinya pikiran anak direstrukturasi supaya mampu memahami bahwa setiap manusia berjenis kelamin dan setiap jenis kelamin memiliki kodratnya masing-masing, serta setiap laki-laki dan perempuan memiliki hasrat seksual yang sama. Kemudian lebih jauh dari itu orang tua atau tenaga pendidik juga menjelaskan bahwa ada terdapat standar etika dalam menyalurkan kebutuuhan seksual, etika yang disandarkan kepada tatanan norma agama dan susila, sehingga dengan mengikuti tatanan tersebut maka kebutuhan seksual akan tersalurkan dengan sehat dan benar. Selain membangun persepsi yang sama terhadap bentuk seksual yang sehat dan ideal, dapat diperkuat dengan menciptakan ruang-ruang sosial yang agamis dan kondusif baik dalam lingkup keluarga atau masyarakat, upaya tersebut dapat membudayakan anak berperilaku beradab (islami) dan terhindari dari perilaku penyimpangan seksual, serta membangun kesadaran anak terhadap bentuk-bentuk seksual yang sehat dan mendorong anak untuk merasa butuh terhadap perbaikan-perbaikan perilaku penyimpangan seksual. 
Nalar: Jurnal Peradaban dan Pemikiran Islam

Vol. 3, No. 1, Juni 2019

Ketiga: Bangun Kesadaran Perbaikan Perilaku Seksual Sebagai Ibadah. Setelah terjadi kesepahaman dan kesamaan persepsi antara anak dan orang tua serta terbangun kesadaran terhadap pentingnya perbaikan perilaku seksual yang menyimpang maka pihak-pihak tersebut akan bersinergi dalam melakukan upaya-upaya perbaikan perilaku seksual menyimpang, dengan melakukan tindakan-tindakan perbaikan tersebut maka anak juga akan memperoleh psychological well-being (Ryff, 1989) atau kepuasan setelah melakukan sesuatu yang berimplikasi baik terhadap dirinya sendiri dan orang lain. Namun untuk menjaga kontinuitas kesadaran tersebut dibutuhkan motivasi untuk menjaga kesadaran yang lebih bersifat jangka panjang, yaitu motivasi agama atau ibadah. Sebab, kepuasan lantaran telah berhasil melakukan perbaikan-perbaikan penyimpangan seksual tidak akan bertahan lama sehingga butuh motivasi agama/ibadah untuk terus menjaga gairah melakukan perbaikan-perbaikan dalam hidup. Kemudian paradigma yang terbangun adalah semakin orang tua atau anak melakukan perbaikan dalam hidup khususnya dalam aspek perilaku seksual, maka akan semakin bernilai ibadah dan mendapat ganjaran pahala (dalam pemahaman agama). Melakukan perbaikan seksual diniatkan sebagai tanggung-jawab diri (khalifah) yang wajib terus melakukan kebaikan dan perbaikan di muka bumi, artinya perbaikan perilaku seksual tidak hanya diorientasikan pada sesuatu yang besifat fisiologis sebagaimana tujuan mewujudkan kesucian diri dan menciptakan kesehatan seksual, namun butuh juga dimaksudkan pada aspek lebih esensial atau syar'i yaitu untuk melaksanakan tugas peribadatan dan menjaga kodrat kesempurnaan penciptaan (ahsanul khuluq) yang telah Allah berikan kepada manusia.

Keempat: Metode Pendidikan Keteladanan dalam Islam. Secara konkret syariat Islam menjelaskan bagaimana sistematika pendidikan seksual dilakukan berdasarkan nash AlQuran dan Hadist yang menyerukan pentingnya tanggungjawab pendidikan seksual terhadap anak, terlebih pada usia anak-anak, pada masa pubertas dan masa remaja sebagai pendidikan dasar untuk menghadapi fase perubahan dan peningkatan kecenderungan seksual anak. Pendidikan seksual dalam Islam bersifat holistik, ditunjukkan oleh objek pendidikan seksual dalam syariat yang tidak hanya mengarah pada anak melainkan juga mengajak kepada bapak dan ibu untuk memulai pendidikan seksual terlebih dahulu, sebab orang tua merupakan lokomotif atau perantara bagi Islam dalam melalui dialektika kebutuhan seksualnya. Berdasarkan kerangka tersebut dapat ditemukan kesinambungan antara dalil Al-Qur'an dengan riwayat-riwayat atau konsep pendidikan lain yang berbasis keteladanan, karena syariat tidak hanya mengatur etika perilaku seksual antara suami-istri, namun etika seksual antara orangtua dan anak-anaknya. Sebab, keluarga merupakan satu sistem bagian yang dapat mempengaruhi bagian yang lain, atau baik dan buruknya hubungan seksual orangtua dapat memberikan pengaruh terhadap kepribadian dan perilaku seksual anak.

Kelima: Merubah Persepsi Anak Terbadap Perilaku Seksual. Terdapat satu hal yang sangat fundamental dan kerap terjadi pada masyarakat muslim yaitu persepsi tentang seksualitas. Islam sangat serius dalam memberikan struktur formal terkait ketentuan-ketentuan seksual dan tidak segan-segan mengutuk pelampiasan seksual yang tidak halal. Fenomena tersebut membuat seksualitas dianggap hal yang tabu, menimbulkan rasa takut yang berlebihan dan enggan memperkenalkan karena takut anaknya tidak paham sehingga terjerumus dalam perbuatan menyimpang. Hakikat seksual penting diperkenalkan untuk merubah persepsi negatif para orangtua, yang berdampak pada semakin menjauhnya pendidikan seksual dengan anak atau remaja. Sebab pengetahuan seksual perlu diketahui sejak dini, supaya anak segera mengetahui normalitas atau abnormalitas seksual serta batas-batas yang mesti diperhatikan dan dihindari, demi terciptanya generasi yang sehat dan bersih dari penyimpangan seksual. Islam memiliki teks-teks syariat yang berisi metodologi yang sempurna terkait pendidikan seksual, teks-teks tersebut hingga saat ini tetap menjadi pagar yang kuat dalam menjaga 
Nalar: Jurnal Peradaban dan Pemikiran Islam

Vol. 3, No. 1, Juni 2019

keluarga muslim hingga pada aspek yang paling tersembunyi dan sensitif (seksual). Namun sebagian orang menganggap remeh teks-teks syariat dan tidak mau mempelajari lebih mendalam sehingga konsekuensinya sebagian dari masyarakat muslim mengetahui sudut pandang Islam terhadap masalah seksual secara samar-samar dan sebagain lain bahkan tidak mengetahui sama sekali.

\section{Penutup}

Berdasarkan analisis di atas dapat diketahui bahwa model pendidikan seksual dalam Islam tidak hanya diorientasikan pada kebaikan masyarakat muslim, melainkan untuk kebaikan tatanan umat manusia. Sebab, pendidikan seksual dalam Islam berpotensi mencegah individu dari perilaku homoseksual dan menjauhkan dari abnormnalitas seksual lainnya. Sehingga menjadi perlu mengkaji secara serius esensi pendidikan dalam Islam kaitannya dengan upaya pencegahan penyimpangan seksual untuk kebaikan tatanan sosial masyarakat muslim dan peradaban manusia pada umumnya. 
Nalar: Jurnal Peradaban dan Pemikiran Islam

Vol. 3, No. 1, Juni 2019

\section{Daftar Pustaka}

AlJauziyah. (2006). Pengobatan Komprehensif terhadap Penyakit Hati. Yogyakarta: Mitra Pustaka.

Ani Khairani, D. S. (2018). Homoseksual Berdasarkan Pandangan Psikologi Islam. Jurnal Ta'dibuna, 7, No.2, Oktober 2018, 1-23.

Azmi, K. R. (2015). Enam Kontinum dalam Konseling Transgender Sebagai Alternatif Solusi untuk Konseli LGBT. Jurnal Psikologi Pendidikan \& Konseling, 1, Nom. 1, Juni 2015, 5255.

Blaikie, N. (2000). Designing Social Research. Firts Published: Polity Press in Association with Blackwell Publishers Ltd.

Dacholfany, I. (2016). Dampak LGBT dan Antisipasinya di Masyarakat. Jurnal NIZAM, 05, 01, Januari-Juni, 2016, 109.

Aziz, S. (2014). Pendidikan Seks Bagi Anak Berkebutuhan Khusus. Jurnal Kependidikan, Vol. II, No. 2 November $2014,187$.

Darajat, Z. (1979). Kesehatan Mental. Jakarta: Gunung Agung.

DepKes, R. (1998). Pedoman Penggolongan dan Diagnosis Gangguan Jiwa di Indonesia, Edisi Ke-III. : DIrektorat Kesehatan Jiwa dan Dirjen Pelayanan Kesehatan.

Earl, B. (1992). The Practice of Social Research. Belmont: Wadswoth Publishing Company.

Hawari, D. (2013). Forbidden Love. Jakarta: Badan Penerbit FKUI.

Husaini, A. (2015). LGBT di Indonesia: Perkembangan dan Solusinya. Jakarta: Insists.

Kartono, K. (2009). Psikologi Abnormal dan Abnormalitas Seksual. Bandung: Mandar Maju.

Kemenag. (2010). Al-Qur'an Tajwid dan Terjemah. Jakarta: PT. Sygma Examedia Arkanleema.

Liputan6. (tanpa tahun, - -). Regional Liputan 6. Dipetik Mei 24, 2019, dari http:// regional.liputan6.com/read/2434716/fenomena-lgbt-di-kalangan-pelajarbatam: http://regional.liputan6.com/read/2434716/fenomena-lgbt-di-kalanganpelajar-batam

Madani, Y. (2003). Pendidikan Seks untuk Anak dalam Islam. Jakarta: Pustaka Zahra.

Montreal, D. (tanpa tahun, - -). http://elsam.or.id. Dipetik Mei 24, 2019, dari http://.elsam.or.id/wp-content/uploads/2014/10/DeclarationofMontralBahasa .pdf: content/uploads/2014/10/DeclarationofMontralBahasa .pdf

Oetomo. (2001). Memberi Suara Pada yang Bisu. Yogyakarta: Galang Press.

Ryff, D. C. (1989). Happiness is everything, or is it? Exploration on the meaning of psychological well being. Journal of Personality and Social Psychology, No. 57.1989, 10691081.

Safrudin. (2014). Pendidikan Seks Bagi Anak Berkebutuhan Khusus. Jurnal Kependidikan, II, No. 2, Novermber, 187.

Soetady, H. U. (2000). Metodologi Penelitian Sosial. Jakarta: PT. Bumi Aksara.

Sri Esti Muryani, D. (2008). Pendidikan Seks Keluarga. Jakarta: Indeks.

Stern, S. (t.thn.). Faktor That Impact Th Health ans Psychological Well Being o Old Adults Shotly Following Institutionalization (translite). Journal of Social Psychology, 46.

Sugiasih, I. (tanpa tahun). Need Assessment Mengenai Pemberian Pendidikan Seksual Yang Dilakukan Ibu Untuk Anak Usia 3-5 Tahun. Jurnal Proyeksi, 6 (1), ISSN : 1907-8455, 74-75.

Syalaby. (2016). Berapa Sebenarnya Jumlah Gay Diseluruh Indonesia. -: - .

Triawan, A. d. (2008). Jadi, kau Tak Merasa Bersalah: Studi Kasus Diskriminasi dan Kekerasan Terbadap LGBT. Jakarta: Citra Grafika. 